Journal of Applied Pharmaceutical Science Vol. 5 (11), pp. 023-030, November, 2015

Available online at http://www.japsonline.com

DOI: $10.7324 / \mathrm{JAPS} .2015 .501104$

ISSN 2231-3354 (cc) BY-NC-SA

\title{
Cytotoxic Triterpenes and Sterols from Pipturus arborescens (Link) C.B. Rob.
}

\author{
Mariquit M. De Los Reyes ${ }^{1,2^{*}}$, Glenn G. Oyong ${ }^{3}$, Virgilio D. Ebajo Jr., Vincent Antonio S. $\mathrm{Ng}^{4}$, Chien-Chang Shen ${ }^{5}$, \\ Consolacion Y. Ragasa ${ }^{4,6}$ \\ ${ }^{1}$ Biology Department, De La Salle University Science \& Technology Complex, Leandro V. Locsin Campus, Biñan City, Laguna 4024, Philippines. \\ ${ }^{2}$ Biology Department, De La Salle University, 2401 Taft Avenue, Manila 0922, Philippines. ${ }^{3}$ Center for Natural Science and Ecological Research, \\ De La Salle University, 2401 Taft Avenue, Manila 0922, Philippines. ${ }^{4}$ Chemistry Department, De La Salle University, 2401 Taft Avenue, Manila 0922 , \\ Philippines. ${ }^{5}$ National Research Institute of Chinese Medicine, Ministry of Health and Welfare, 155-1, Li-Nong St., Sec. 2, Taipei 112, Taiwan. \\ ${ }^{6}$ Chemistry Department, De La Salle University Science \& Technology Complex, Leandro V. Locsin Campus, Biñan City, Laguna 4024, Philippines.
}

\begin{tabular}{|c|c|}
\hline ARTICLE INFO & ABSTRACT \\
\hline Article history: & \multirow{12}{*}{ 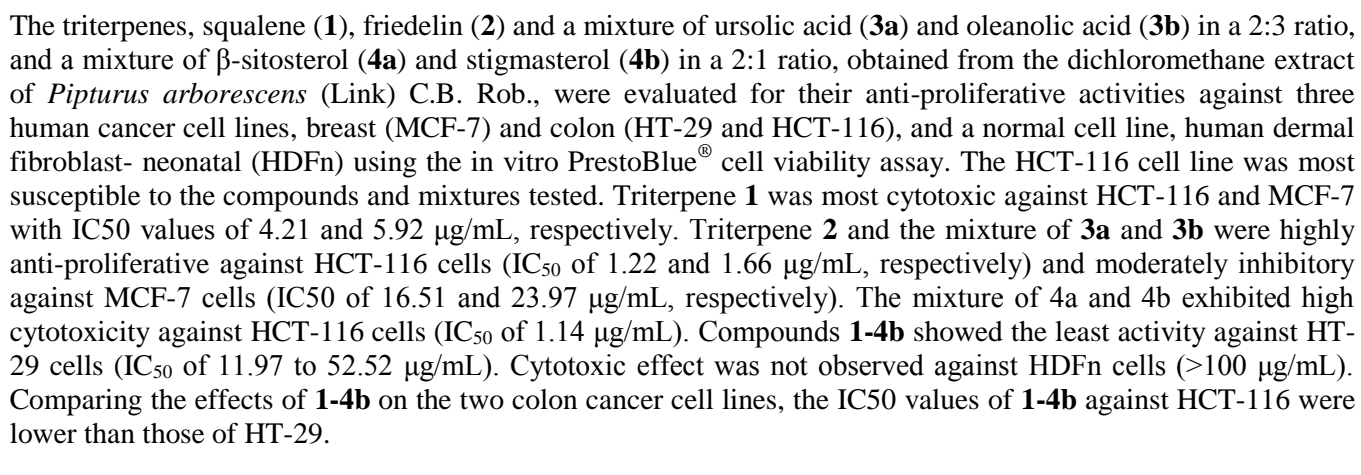 } \\
\hline Received on: $29 / 06 / 2015$ & \\
\hline & \\
\hline & \\
\hline$/ 11 / 2015$ & \\
\hline & \\
\hline Pipturus arb & \\
\hline & \\
\hline & \\
\hline oleanolic acid, $\beta$-sitosterol, & \\
\hline stigmasterol, cytotoxicity, & \\
\hline $\begin{array}{l}\text { MCF-7, HCT-116, HT-29, } \\
\text { HDFn. }\end{array}$ & \\
\hline
\end{tabular}

\section{INTRODUCTION}

Pipturus arborescens (Link) C.B. Rob. belongs to the family, Urticaceae, and is widely distributed in the Philippines where it is locally known as "dalunot" or "handalamay". It is dioecious, reaches up to $5 \mathrm{~m}$ tall and commonly grows in thickets and secondary forests at low and medium altitudes in China, Taiwan, Japan and Borneo, but ascends to $2000 \mathrm{~m}$ asl in the Philippines (Chen et al., 2004; Pelser et al., 2011). Aside from being a source of edible fruits, scrapings from the bark are used

\footnotetext{
* Corresponding Author

Mariquit M. De Los Reyes, Biology Department, De La Salle University Science \& Technology Complex, Leandro V. Locsin Campus, Biñan City, Laguna 4024, Philippines and Biology Department, De La Salle University, 2401 Taft Avenue, Manila 0922, Philippines mariquit.delosreyes@dlsu.edu.ph
}

externally as poultice for boils while the leaves are used for the treatment of herpes (Van Valkenburg, 2001; Esperanza and Kitche, 2005; Quisumbing, 1978). Previous works using ethyl acetate extracts of $P$. arborescens leaves showed antibacterial activity against Bacillus subtilis (Rosal, 1995). Methanol extracts of the plant exhibited potency against Staphylococcus aureus and Escherichia coli (Enerio, 2007). Another study evaluating the cytotoxic and anti-oxidant properties of the plant showed that the crude methanol extract of the leaves exhibited an $\mathrm{LC}_{50}$ of 57.5 $\mu \mathrm{g} / \mathrm{mL}$ in the brine shrimp lethality assay and an $\mathrm{EC}_{50}$ of 838 $\mu \mathrm{g} / \mathrm{mL}$ in the DPPH free radical scavenging assay (Peteros and Uy, 2010).

A phytochemical screening of $P$. arborescens leaves indicated the presence of tannins, saponins, flavonoids and alkaloids from the chloroform extracts (Uy and Rivera, 2011). 
Other previous studies using $P$. arborescens leaves yielded the triterpenes, glutinone, friedelin and glutinol, and a mixture of sterols, campesterol, stigmasterol and sitosterol from the hexane extracts (Gabona, 2000) and ficaprenol-10 and squalene from the methanol extracts (Peteros, 2010). There are few reports on the genus Pipturus. Only two other species, $P$. albidus and $P$. argenteus, have been studied. Studies on $P$. albidus yielded three phenolic acids, catechin, chlorogenic acid and rutin (Kartika et al., 2007) and led to the discovery of its potential antimicrobial activity against $S$. aureus and $S$. pyogenes (Locher et al., 1995). Both ethanol and water extracts from the leaves and bark of $P$. albidus exhibited a highly selective inhibition of the replication of the human immunodeficiency Virus Type-1 (HIV-1) with low cytotoxicity on normal cells (Locher et al., 1996). A study on the extracts of $P$. argenteus, along with Phyllanthus pulcher and/or Piper betel led to the development of a skin aging preventing cream (Mitani et al., 2000a). Another study on $P$. argenteus, Rauwolfia serpentine and Oxalis corniculata showed the usefulness of the extracts as melanin production inhibitor (Mitani et al., 2000b). Recently, we reported the isolation of ursolic acid, oleanolic acid, friedelin, $\beta$-sitosterol, and stigmasterol from the twigs; and $\beta$-sitosterol, stigmasterol, squalene, chlorophyll a, and polyprenol from the leaves of $P$. arborescens (Ragasa et al., 2014). We report herein the cytotoxicity potentials of squalene (1), friedelin (2), 2:3 ratio of ursolic acid (3a) and oleanolic acid (3b), and 2:1 ratio of $\beta$-sitosterol (4a) and stigmasterol (4b), obtained from $P$. arborescens, against three human cancer cell lines, breast (MCF-7) and colon (HT-29 and HCT-116), and a normal cell line, human dermal fibroblast, neonatal (HDFn). To the best of our knowledge, this is the first report on the anti-proliferative properties of $\mathbf{1 - 4 b}$ from $P$. arborescens against the human cancer cell lines mentioned.

\section{MATERIALS AND METHODS}

\section{Sample collection}

Samples of leaves and twigs of Pipturus arborescens (Link) C.B. Rob were collected from the De La Salle UniversityScience and Technology Complex (DLSU-STC) riparian forest in February 2014. The samples were authenticated and deposited at the De La Salle University Herbarium with voucher specimen \# 921.

\section{Isolation and structure elucidation}

The isolation and structure elucidation of $\mathbf{1 - 4 b}$ from the leaves and twigs of $P$. arborescens were reported previously (Ragasa et al., 2014).

\section{Preparation of compounds}

The triterpenes (1-3b) and sterols (4a and 4b) from $P$. arborescens were dissolved in dimethyl sulfoxide (DMSO) to make a $4 \mathrm{mg} / \mathrm{mL}$ stock solution. Working solutions were prepared in complete growth medium to a final non-toxic DMSO concentration of $0.1 \%$.

\section{Maintenance and preparation of cells}

The bioactivity of the dichloromethane $\left(\mathrm{CH}_{2} \mathrm{Cl}_{2}\right)$ extracts from $P$. arborescens was tested on the following human cell lines: breast cancer (MCF-7), colon cancer (HCT-116 and HT29), and human dermal fibroblast, neonatal (HDFn)(ATCC, Manassas, Virginia, U.S.A.) which are routinely maintained at the Cell and Tissue Culture Laboratory, Molecular Science Unit, Center for Natural Science and Ecological Research, De La Salle University.

Following standard procedures (Freshney, 2000), cells were grown in Dulbecco's Modified Eagle Medium (DMEM, Gibco $^{\circledR}$, USA) containing $10 \%$ fetal bovine serum (FBS, Gibco ${ }^{\circledR}$, USA) and $1 \mathrm{x}$ antibiotic-antimycotic $\left(\mathrm{Gibco}^{\circledR}\right.$, USA) and kept at $37^{\circ} \mathrm{C}$ with $5 \% \mathrm{CO}_{2}$ in a $98 \%$ humidified incubator. Upon reaching $80 \%$ confluence, the monolayer cultures were washed with phosphate-buffered saline (PBS, pH 7.4, Gibco ${ }^{\circledR}$, USA), trypsinized with $0.05 \%$ Trypsin-EDTA (Gibco ${ }^{\circledR}$, USA) and resuspended with complete fresh media. Cells were counted following standard trypan blue exclusion method using $0.4 \%$ Trypan Blue Solution (Gibco ${ }^{\circledR}$, USA). Cells were later seeded in $100 \mu \mathrm{L}$ aliquots into 96-well microtiter plates (Falcon ${ }^{\mathrm{TM}}$, USA) using a final inoculation density of $1 \times 10^{4}$ cells/well. The plates were further incubated overnight at $37^{\circ} \mathrm{C}$ with $5 \% \mathrm{CO}_{2}$ in a $98 \%$ humidified incubator until complete cell attachment was achieved. These plates were used for the bioassay as described below.

\section{Cell viability assay}

The cytotoxicity of the $P$. arborescens compounds was determined in a cell viability test using PrestoBlue ${ }^{\circledR}$ (Molecular Probes $^{\circledR}$, Invitrogen, USA). The bioassay is based on the presence of mitochondrial reductase in viable cells that converts the resazurin dye (blue and nonfluorescent) to resorufin (red and highly fluorescent). The conversion is proportional to the number of metabolically active cells and is determined quantitatively using absorbance measurements. To the monolayers in the microtiter plate, $100 \mu \mathrm{L}$ of filter-sterilized $\mathbf{1 - 4 \mathbf { b }}$ were added to corresponding wells at two-fold serial dilutions to make final screening concentrations of $50,25,12.5,6.25,3.12,1.56,0.78$, and 0.39 $\mu \mathrm{g} / \mathrm{mL}$.

The treated cells were further incubated for 4 days at $37^{\circ} \mathrm{C}$ in $5 \% \quad \mathrm{CO}_{2}$ and $98 \%$ humidity. Twenty microliters of PrestoBlue ${ }^{\circledR}$ was added to each well. The cells were incubated for $1 \mathrm{hr}$ at $37^{\circ} \mathrm{C}$ in $5 \% \mathrm{CO}_{2}$ and $98 \%$ humidity. Wells with no sample added served as negative controls, wells with Zeocin ${ }^{\mathrm{TM}}$ (Gibco ${ }^{\circledR}$, USA) served as positive controls. Absorbance measurements were carried out using BioTek ELx800 Absorbance Microplate Reader (BioTek ${ }^{\circledR}$ Instruments, Inc.) at $570 \mathrm{~nm}$ and normalized to $600 \mathrm{~nm}$ values (reference wavelength). Absorbance readings were used to calculate for the cell viability for each sample concentration following the equation below.

$$
\begin{aligned}
& \text { Cell Viability }(\%) \\
& =\frac{(\text { Absorbance of Treated Sample }- \text { Absorbance of Blank })}{(\text { Absorbance of Negative Control }- \text { Absorbance of Blank })} \times 100
\end{aligned}
$$


Nonlinear regression and statistical analyses were done using GraphPad Prism 6.05 (GraphPad Software, Inc.) to extrapolate the half maximal inhibitory concentration, $\mathrm{IC}_{50}$ (the concentration of the compound which resulted in a $50 \%$ reduction in cell viability). The cytotoxicity of $\mathbf{1 - 4 b}$ was expressed as $\mathrm{IC}_{50}$ values. All tests were performed in triplicates and data were shown as mean \pm SEM. The extra sum-of-squares F-test was used to evaluate the differences in the best-fit parameters (half maximal inhibitory concentration) among data sets (treatments) and to determine the differences among dose-response curve fits according to the software's recommended approach. One-way ANOVA $(\mathrm{p}<0.05)$ was also conducted to determine significant differences among group variables, followed by the multiple comparison, Tukey's post hoc test $(\mathrm{p}<0.05)$, to compare different pairs of data sets. Results were considered significant at $\mathrm{p}<0.05$.

\section{RESULTS AND DISCUSSION}

This study presents investigations on the cytotoxic activities of squalene (1), friedelin (2), 2:3 ratio of ursolic acid (3a) and oleanolic acid (3b) and 2:1 ratio of $\beta$-sitosterol (4a) and stigmasterol (4b) (Figure 1), previously isolated from the dichloromethane extracts of $P$. arborescens leaves and twigs (Ragasa et al., 2014), against three human cancer cell lines, breast (MCF-7) and colon (HT-29 and HCT-116), and a human normal cell line, human dermal fibroblast, neonatal (HDFn). Zeocin, a known anti-cancer drug, was used as positive control. Figures 2 and 3 shows the \% cell viability as a function of the logarithmic values of sample concentration. The plots mostly follow the typical sigmoidal curve characteristic of an inhibitory doseresponse relationship. Figure 2 compares the anti-proliferative effect of all samples per cell line, while Figure 3 compares the effect on cell viability of a sample against all the cell lines used. The corresponding $\mathrm{IC}_{50}$ values are summarized in Table 1.

Table 1. Cytotoxic activities (IC50) of 1-4b and Zeocin against MCF-7, HCT116, HT-29 and HDFn.

\begin{tabular}{ccccc}
\hline \multirow{2}{*}{ Compound } & \multirow{2}{*}{ MCF-7 } & \multicolumn{3}{c}{ IC $_{\mathbf{5 0}} *(\boldsymbol{\mu g} / \mathbf{m l})$} \\
\cline { 3 - 5 } & & HCT-116 & HT-29 & HDFn \\
\hline 1 & 5.92 & 4.21 & 52.52 & $>100$ \\
2 & 16.51 & 1.22 & 33.63 & $>100$ \\
3a and 3b & 23.97 & 1.66 & 29.46 & $>100$ \\
4a and 4b & 8.62 & 1.14 & 11.97 & $>100$ \\
Zeocin & 1.19 & 0.36 & 0.36 & 3.99 \\
\hline
\end{tabular}

* $\mathrm{IC}_{50}$ values were extrapolated from dose-response curves generated from nonlinear regression analysis done using GraphPad Prism 6.05 (GraphPad Software, Inc.). For each cell line, one-way ANOVA was conducted to determine significant differences among data sets. The results are: MCF-7, $\mathrm{F}(5,126)=159.6 \mathrm{p}<0.0001 ;$ HCT-116, $\mathrm{F}(5,126)=98.14, \mathrm{p}<0.0001 ;$ HT-29, $\mathrm{F}(5,122)=266.6, \mathrm{p}<0.0001 ;$ HDFn, $\mathrm{F}(5,115)=0.0006892, \mathrm{p}>0.9999$.

The breast cancer cell line (MCF-7) is most susceptible to $\mathbf{1}$ and $\mathbf{4 a}$ and $\mathbf{4 b}$, with $\mathrm{IC}_{50}$ values of 5.92 and $8.62 \mu \mathrm{g} / \mathrm{mL}$, respectively, followed by $\mathbf{2}$ and $\mathbf{3 a}$ and $\mathbf{3 b}$, with $\mathrm{IC}_{50}$ values of 16.51, and $23.97 \mu \mathrm{g} / \mathrm{mL}$, respectively. Tukey's multiple comparison post hoc test showed that there was no significant difference between the $\mathrm{IC}_{50}$ values for $\mathbf{1}$ and $\mathbf{4 a}$ and $\mathbf{4 b}(\mathrm{p}>0.05)$, as well as between $\mathbf{2}$ and $\mathbf{3 a}$ and $\mathbf{3 b}(\mathrm{p}>0.05)$. However, significant differences were established between other pairs of treatments ( $\mathrm{p}<0.0001)$. The colon cancer cell line, HCT-116, was most susceptible to $\mathbf{4 a}$ and $\mathbf{4 b}$ and $\mathbf{2}$, with $\mathrm{IC}_{50}$ values of 1.14 and $1.22, \mu \mathrm{g} / \mathrm{mL}$, respectively, followed by $\mathbf{3 a}$ and $\mathbf{3 b}$ and $\mathbf{1}$, with $\mathrm{IC}_{50}$ values of 1.66 , and $4.21 \mu \mathrm{g} / \mathrm{mL}$, respectively. The $\mathrm{IC}_{50}$ values for $\mathbf{4 a}, \mathbf{4 b}$ and $\mathbf{2}$ are comparable ( $p>0.05$ ) while those between $\mathbf{3 a}, \mathbf{3 b}$ and $\mathbf{1}$ are statistically different $(\mathrm{p}<0.0001)$.
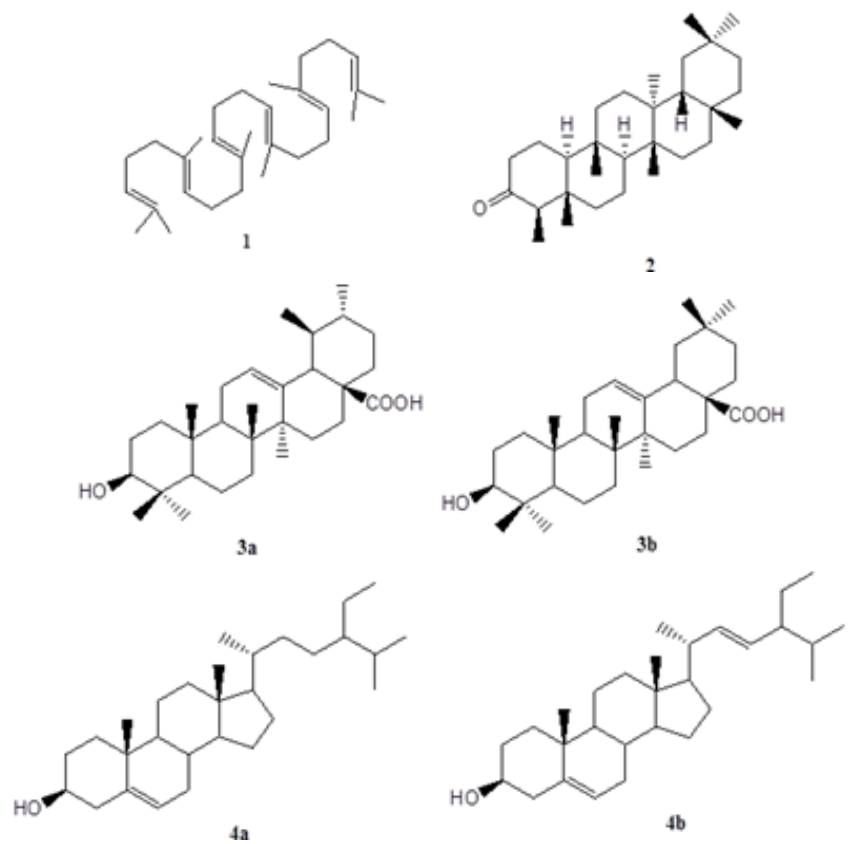

Fig. 1: Chemical structures of squalene (1), friedelin (2), ursolic acid (3a), oleanolic acid (3b), $\beta$-sitosterol (4a) and stigmasterol (4b).

The growth of the other colon cancer cell line, HT-29, was inhibited only at higher concentrations of the compounds, with $\mathrm{IC}_{50}$ values of $11.97,29.46,33.63$, and $52.52 \mu \mathrm{g} / \mathrm{mL}$ for $\mathbf{4 a}$ and $\mathbf{4 b}, \mathbf{3 a}$ and $\mathbf{3 b}, \mathbf{2}$ and $\mathbf{1}$, respectively. The $\mathrm{IC}_{50}$ value for $\mathbf{4 a}$ and $\mathbf{4 b}$ is significantly different from those of the other compounds ( $\mathrm{p}<0.0001)$. The normal cell line, HDFn cell, did not exhibit cytotoxicity to any of the samples, with $\mathrm{IC}_{50}$ values of $>100 \mu \mathrm{g} / \mathrm{mL}$ in all cases $(p>0.05)$. On the other hand, all the cell lines exhibited cytotoxicity to Zeocin, with $\mathrm{IC}_{50}$ values of $1.19,0.36$, 0.36, and $3.99 \mu \mathrm{g} / \mathrm{mL}$ for MCF-7, HCT-116, HT-29 and HDFn, respectively. Statistical analysis comparing dose-response curves for all treatments showed significant differences among best-fit values (half maximal inhibitory concentration) for all cell lines and treatments (Figures 3 and 3). Overall, comparing the three human cancer cell lines, HCT-116 was the most reactive to $\mathbf{1 - 4 b}$, requiring the least half maximal inhibitory concentrations. This was followed by MCF-7 cell line which was moderately affected by 1-4b. The cell line HT-29 reacted the least to $\mathbf{1 - 4 b}$. Other studies showed similar reaction where HCT-116 cells were found to be more reactive to cytotoxic compounds compared to MCF-7 (Abeer et al., 2011; Kumar et al., 2015; Malek et al., 2011; Mohammed et al., 2011; Sung et al., 2015). Compound 1 was most effective against colon cancer cells HCT-116 and breast cancer cells $\mathrm{MCF}-7$, with $\mathrm{IC}_{50}$ values of 4.21 and $5.92 \mu \mathrm{g} / \mathrm{mL}$, 
respectively. Triterpene $\mathbf{2}, \mathbf{3 a}$ and $\mathbf{3 b}$, and $\mathbf{4 a}$ and $\mathbf{4 b}$ exhibited high cytotoxicity against HCT-116 cells $\left(\mathrm{IC}_{50}\right.$ values of $1.22,1.66$ and $1.14 \mu \mathrm{g} / \mathrm{mL}$, respectively). Only the mixture of $\mathbf{4 a}$ and $\mathbf{4 b}$ was found to be moderately inhibitory against HT-29 ( $\mathrm{IC}_{50}$ value of $11.97 \mu \mathrm{g} / \mathrm{mL})$. None of the samples was cytotoxic to the normal cells HDFn $(>100 \mu \mathrm{g} / \mathrm{mL}$ in all cases). The US National Cancer Institute has defined the active cytotoxic limits of natural products as $20 \mu \mathrm{g} / \mathrm{mL}$ or less for crude extracts and $4 \mu \mathrm{g} / \mathrm{mL}$ or less for pure compounds (Geran et al., 1972). Pure compounds that exhibit active cytotoxicity may have some potential for drug development (Jacinto et al., 2011). The results showed that 1-4b from Pipturus arborescens can be further developed for the treatment of cancer against the human colorectal type, HCT-116, and human breast, MCF-7.

The study showed that the cytotoxic activity of $\mathbf{1 - 4 b}$ depended on the specific type of cancer cell being targeted. When the two colon cancer cell lines (HCT-116 and HT-29) are compared, the $\mathrm{IC}_{50}$ values of $\mathbf{1 - 4 b}$ for HCT-116 were lower, implying that HCT-116 is more responsive to anti-cancer treatments using the samples tested. It was reported that differences in the expression profiles of several genes associated with drug sensitivity between HCT-116 and HT-29 could be an important factor in how the cells respond to different inhibitory compounds (Makizumi et al., 2008). A related study using four human colon cancer cells (HCT-116, HT-29, HCT-15, KM-12) showed that gene expression profiling after inhibition of signal transduction by 17-allylamino-17-demethoxygeldanamycin, an inhibitor of the hsp90 molecular chaperone, could explain why cells responded differently under similar treatment conditions (Clarke et al., 2000).

Previous studies revealed that squalene, friedelin, ursolic acid, oleanolic acid, $\beta$-sitosterol and stigmasterol exhibited cytotoxic and anticancer properties.

Squalene (1) was reported to significantly suppress colonic aberrant crypt foci (ACF) formation and crypt multiplicity in laboratory rats which strengthened the hypothesis that it possesses chemopreventive activity against colon carcinogenesis (Rao et al., 1998). In a study evaluating the bioactivity of tocotrienols, carotenoids, squalene and coenzyme Q10 from palm oil with respect to the anti-proliferative effects on two human breast cancer cell lines, MDA-MB-231 and MCF-7, it was found that there was a suppression of nuclear factor kappa-light-chainenhancer of activated B-cells (NF- $\mathrm{B}$ ) protein in the breast cancer cells exposed briefly to tumor necrosis factor-alpha (TNF- $\alpha$ ) (Loganathan et al., 2013; Loganathan et al., 2015). The preventive and therapeutic effects of squalene-containing compounds on tumor promotion and regression have been reported (Desai et al., 1996). Recent reviews on the bioactivities of squalene have been provided (Ronco and De Stéfani, 2013; Chudzik et al., 2015). Thus, 1 was reported to exhibit cytotoxic properties against colon and breast cancer cell lines which corroborate our findings that $\mathbf{1}$ showed high cytotoxicity against colon cancer cells HCT-116 and breast cancer cells MCF-7, with $\mathrm{IC}_{50}$ values of 4.21 and $5.92 \mu \mathrm{g} / \mathrm{mL}$, respectively.
Friedelin (2) showed significant anti-proliferative effects against both human cervical cancer cell line (HeLa) and human cutaneous squamous carcinoma cell line (HSC-1) (Prabhu et al., 2013). In another study, 2 exhibited the strongest inhibitory activity against $\mathrm{HeLa}$ cancer cells with an $\mathrm{IC}_{50}$ of $3.54 \mu \mathrm{g} / \mathrm{ml}$ (Utami et al., 2013). It also displayed anti-proliferative properties against human melanoma cells (A375), mouse lung epithelial tumor cells (L929), human cervical tumor cells (Hela), and human macrophage tumor cells (THP-1) in a time- and dose-dependent manner ( $\mathrm{Lu}$ et al., 2010). Triterpene 2 was found to exhibit growth inhibitory activities against MBA-MD-231 human breast cancer cells (Ee et al., 2005). It was reported that the synergistic effects of 2, 28-hydroxy-3-friedelanone and 7-methoxy-coumarin inhibited the growth of acute promyelocytic leukemia cells lines NB4 and HT93A (Sangsuwon et al., 2013). Thus, 2 was reported to exhibit cytotoxic effect against human breast cancer cells which corroborate the cytotoxic property of $\mathbf{2}$ found in our study. Our study also showed that $\mathbf{2}$ was highly effective against colon cancer cells HCT-116 with an $\mathrm{IC}_{50}$ value of $1.22 \mu \mathrm{g} / \mathrm{mL}$.

Ursolic acid (3a) was found to induce apoptosis in tumor cells by activation of caspases and modulation of pathways affecting cell proliferation and migration (Neto, 2011). It also decreased proliferation and induced apoptosis in gastric cancer cell line BGC-803 and hepatocellular cancer cell H22 xenograft, both in vivo and in vitro (Wang et al., 2011). Previous studies showed that 3a exhibited anti-tumor activity against human colon carcinoma cell line HCT15 (Li et al., 2002) and inhibited the growth of colon cancer-initiating cells by targeting STAT3 (Wang et al., 2013). Triterpene $\mathbf{3 a}$ and betulinic acid were found responsible for the anti-estrogenic effects suggesting its potential use as therapeutic agents against estrogen-dependent tumors (Kim et al., 2014a). Furthermore, 3a has potential therapeutic use also against prostate cancer through its anti-proliferative and apoptotic effects (Kassi et al., 2007). A recent study reported that 3a inhibited cell growth and proliferation of Jurkat leukemic T-cells, inhibiting PMA/PHA induced IL-2 and TNF- $\alpha$ production in a concentration and time dependent manner (Kaewthawee and Brimson, 2013). A study on cervical cancer cells TC-1 reported that ursolic acid-activated autophagy induced cytotoxicity and reduced tumor growth in a concentration-dependent manner Leng et al., 2013). Another study evaluated the antitumor activities of 3a on U87MG brain cancer cells and found that both G1-phase arrest and autophagy were induced by the compound (Shen et al., 2014). In a study evaluating the anticancer properties of ursolic acid and three flavonoids, daidzein, baicalein, and hesperidin, it was found that $\mathbf{3 a}$ and baicalein inhibited the proliferation of MCF-7 breast cancer cells induced by PhIP, a food-derived carcinogen with estrogenic activity (Lee et al., 2010). The anticancer potential of $\mathbf{3 a}$ in different berries has been provided (Neto, 2011). Oleanolic acid (3b) was found to be anti-mutagenic and anti-tumor, inhibiting proliferation of gastric, colon, and liver cancer cells by inducing apoptosis and necrosis (Zhang et al., 2011). Triterpene 3b was found to inhibit mouse skin tumor (Oguro et al., 1998) and exhibited significant anti-tumor activity 
against human colon carcinoma cell line HCT 15 (Li et al., 2002). A recent study identified $\mathbf{3 b}$ as an anti-tumor compound able to suppress aerobic glycolysis in MCF-7 breast cancer cells by inducing a metabolic switch in the PKM2 to PKM1 ratio which is important in cancer development (Liu et al., 2014). Thus, 3a and 3b were reported to exhibit cytotoxic properties against colon and breast cancer cell lines which corroborate our findings that a mixture of $\mathbf{3 a}$ and $\mathbf{3 b}$ showed high cytotoxicity against colon cancer cells $\mathrm{HCT}-116$ with an $\mathrm{IC}_{50}$ value of $1.66 \mu \mathrm{g} / \mathrm{mL}$ and moderate cytotoxicity against breast cancer cells MCF-7, with an $\mathrm{IC}_{50}$ value of $23.97 \mu \mathrm{g} / \mathrm{mL}$.

$\beta$-Sitosterol (4a) was observed to influence the programmed cell death pathway in human breast cancer cells (MCF-7) and human adenocarcinoma cells (MDA-MB-231), inhibiting tumor proliferation by promoting apoptosis (Awad et al., 2007). It also inhibited cell proliferation of human colon cancer cell line (HT-29) (Jayaprakasha et al., 2007). In vitro studies showed that $\mathbf{4 a}$ inhibited the growth of human colon cancer cells (COLO 320 DM) with an $\mathrm{IC}_{50}$ of $266.2 \mu \mathrm{M}$, inducing apoptosis by scavenging oxidants and attenuating $\beta$-catenin and PCNA expression while in vivo studies proved that 4 a reduced the number of aberrant crypt and crypt multiplicity in DMH-initiated rats in a dose-dependent manner (Baskar et al., 2010). It significantly reduced the expression of Niemann-Pick C1-like 1 (NPC1L1) in human small intestine epithelial cell line (FHs 74 Int) to reduce intestinal cholesterol absorption at the cellular level (Jesch et al., 2009). It also induced apoptosis mediated by the activation of ERK and the downregulation of Akt in murine fibrosarcoma cells (MCA-102) (Moon et al., 2007). Sterol 4a inhibited the growth of HT116 human colon cancer cells by a number of mechanisms including the activation of caspase- 3 and caspase- 9 accompanied by proteolytic cleavage of poly(ADPribose)-polymerase and the reduction of the expression of the antiapototic Bcl-2 protein and mRNA and a subsequent increase of the pro-apototic Bax protein and mRNA (Choi et al., 2003). Stigmasterol (4b) decreased tumor volume and cell viability, increasing the life span of Ehrlich ascites carcinoma (EAC)bearing mice (Ghosh, 2011). It was reported that $\mathbf{4 a}$ and $\mathbf{4 b}$ exhibited anti-proliferative activities against human prostate cancer cells (DU-145) by increasing p53 protein expression and inhibiting carcinoma development by decreasing p21 and p27 protein expression (Scholtysek et al., 2009). Other studies reported that $\mathbf{4 b}$ showed cytostatic activity against HEp-2 and McCoy cells (Gómez et al., 2001), significantly inhibited tumor promotion in mouse skin two-stage carcinogenesis experiments (Kasahara et al., 1994), and demonstrated antimutagenic (Lim et al., 2005), and anti-oxidant (Panda et al., 2009) properties. A recent report showed that $\mathbf{4 b}$ induced apoptosis in hepatocarcimona cells (HepG2) by up-regulating the expression of pro-apoptotic gene expressions (Bax, p53) while down-regulating the anti-apoptotic genes (Bcl-2), activating caspase- 8 and caspase- 9 in the process (Kim et al., 2014b). Thus, $\mathbf{4 a}$ and $\mathbf{4 b}$ were reported to exhibit cytotoxic properties against several cancer cell lines. $\beta$-Sitosterol was reported to possess cytotoxicity against colon and breast cancer cell lines which corroborate our findings that a mixture of 4a and $4 \mathbf{b}$ showed high cytotoxicity against colon cancer cells HCT-116 and breast cancer cells MCF-7, with $\mathrm{IC}_{50}$ values of 1.14 and $8.62 \mu \mathrm{g} / \mathrm{mL}$, respectively.
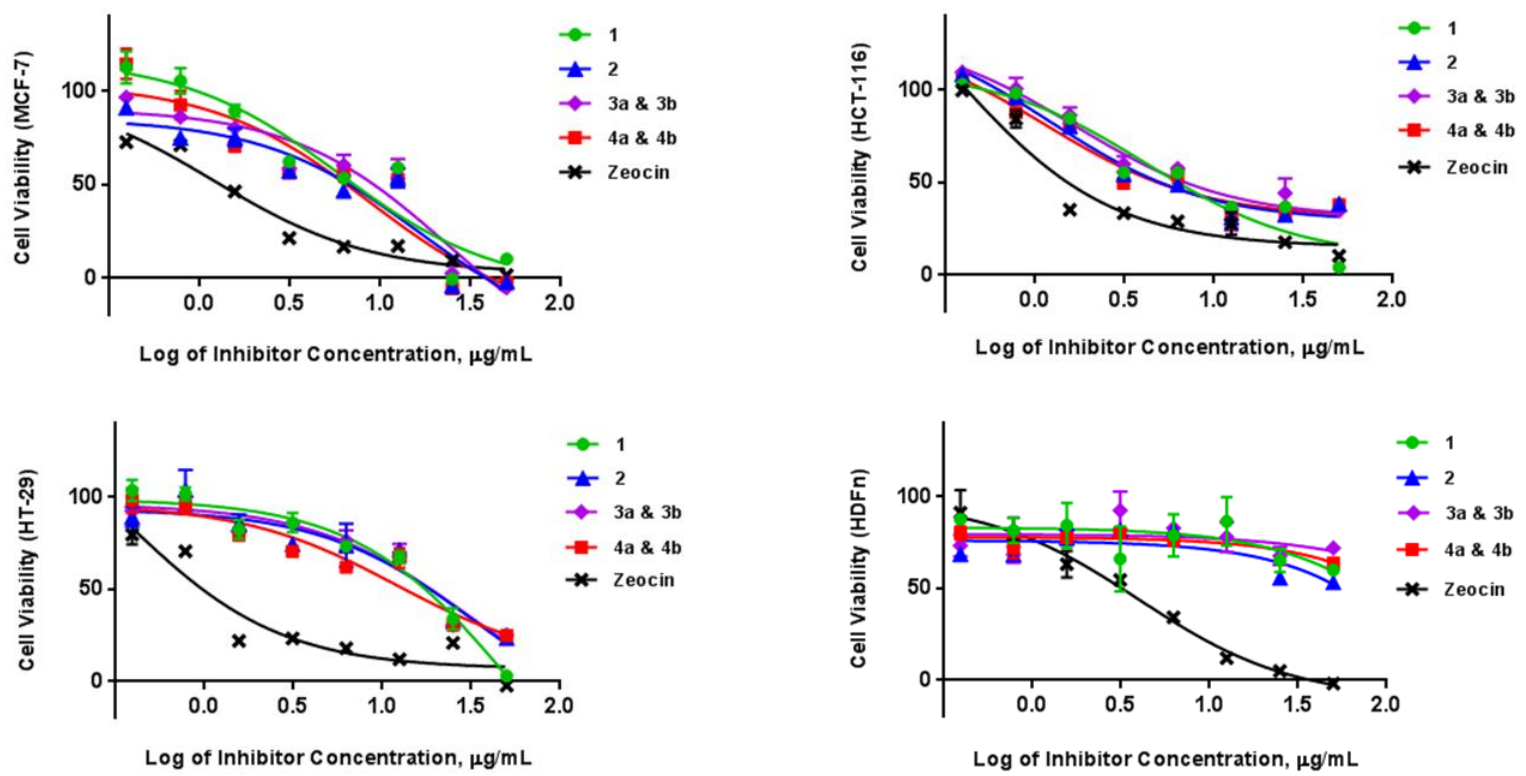

Fig. 2. Dose-response curves showing the cytotoxic activities of 1-4b and Zeocin on the cell viability of MCF-7, HCT-116, HT-29 and HDFn. Each plot shows the effect of 1-4b and Zeocin against each cell line. Data are shown as mean \pm SEM. GraphPad Prism 6.05 was used to perform extra sum-of-squares F-test to (A) evaluate the significance of the best-fit parameter (half maximal inhibitory concentration) among different treatments, and to (B) determine the differences among the dose-response curve fits. The results are: $\mathrm{MCF}-7$ (A) F(DFn, DFd $)=\mathrm{F}(5,126)=5.560, \mathrm{p}<0.0001$ and $(\mathrm{B}) \mathrm{F}(15,126)=15.61, \mathrm{p}<0.0001 ; \mathrm{HCT}-116$ (A) $\mathrm{F}(5,126)=6.555, \mathrm{p}<0.0001$ and $(\mathrm{B}) \mathrm{F}(15,126)=34.30, \mathrm{p}<0.0001 ; \mathrm{HT}-29$ (A) $\mathrm{F}(5,122)=16.17, \mathrm{p}<0.0001$ and $(\mathrm{B}) \mathrm{F}(15,122)=37.58, \mathrm{p}<0.0001$; HDFn (A) $\mathrm{F}(5,115)=4.065, \mathrm{p}<0.002$ and (B) $\mathrm{F}(15,115)=23.26, \mathrm{p}<0.0001$ 

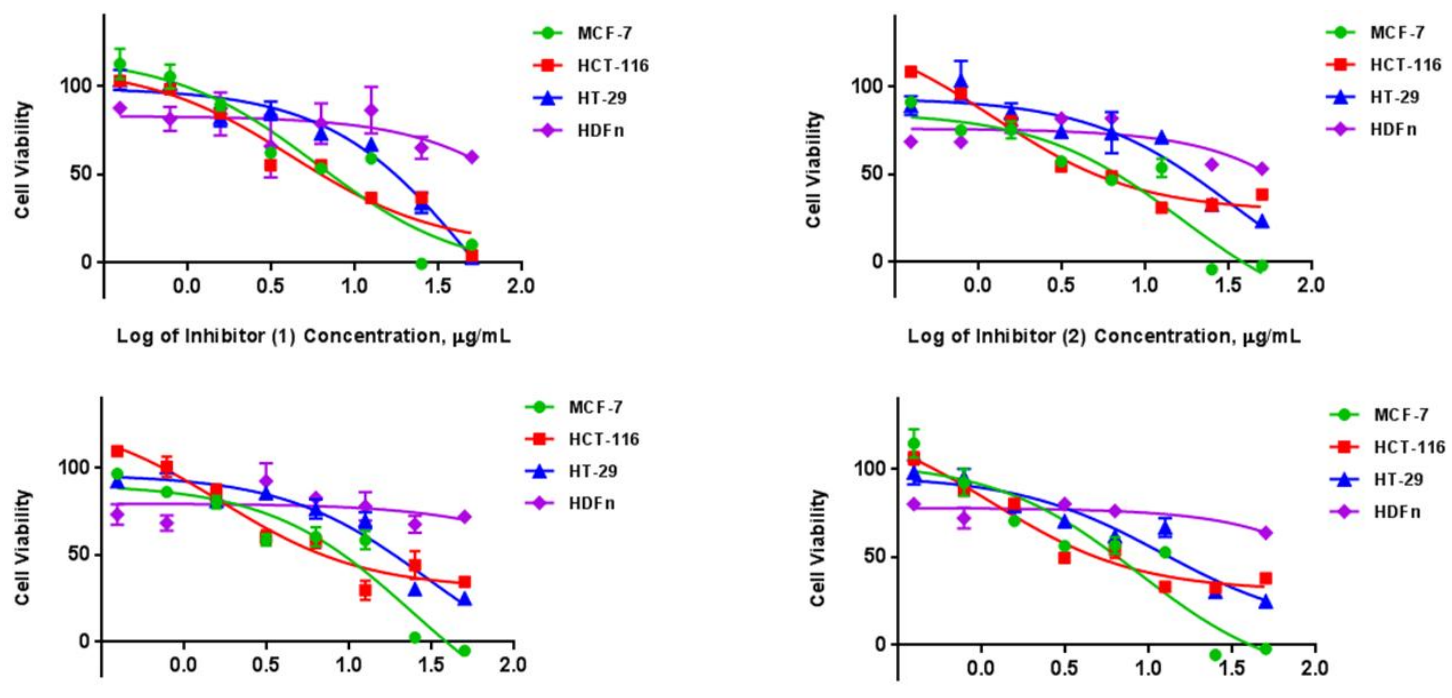

Log of Inhibitor (3a \& 3b) Concentration, $\mu \mathrm{g} / \mathrm{mL}$

Log of Inhibitor (4a \& 4b) Concentration, $\mu \mathrm{g} / \mathrm{mL}$

Fig. 3: Dose-response curves showing the cytotoxic activities of 1-4b on the cell viability of MCF-7, HCT-116, HT-29 and HDFn. Each plot shows the effect of a sample against all cell lines tested. Data are shown as mean \pm SEM. GraphPad Prism 6.05 was used to perform extra sum-of-squares F-test to (A) evaluate the significance of the best-fit parameter (half maximal inhibitory concentration) among different treatments, and to (B) determine the differences among doseresponse curve fits. The results are: compound 1 (A) $F(D F n, D F d)=F(3,82)=5.594, p<0.0015$ and (B) $F(9,82)=13.87, p<0.0001 ; \quad$ compound 2 (A) $F(3$, $77)=16.29, \mathrm{p}<0.0001$ and $(\mathrm{B}) \mathrm{F}(9,77)=20.03, \mathrm{p}<0.0001$; mixture $3 \mathrm{a}$ and $3 \mathrm{~b}(\mathrm{~A}) \mathrm{F}(3,84)=12.12, \mathrm{p}<0.0001$ and $(\mathrm{B}) \mathrm{F}(9,84)=22.70, \mathrm{p}<0.0001$; mixture $4 \mathrm{a}$ and $4 \mathrm{~b}(\mathrm{~A}) \mathrm{F}(3,78)=5.897, \mathrm{p}<0.0011$ and $(\mathrm{B}) \mathrm{F}(9,78)=13.77, \mathrm{p}<0.0001$.

\section{CONCLUSION}

The triterpenes, squalene (1), friedelin (2)and a 2:3 ratio of ursolic acid (3a) and oleanolic acid (3b), and sterols, $\beta$ sitosterol (4a) and stigmasterol (4b) in a 2:1 ratio, obtained from the dichloromethane extracts of $P$. arborescens, exhibited varying cytotoxic activities against human cancer cell lines, breast (MCF7) and colon (HT-29 and HCT-116). Overall, the anti-proliferative activities of 1-4b were highest against HCT-116, with $\mathrm{IC}_{50}$ values ranging from 1.14 to $4.21 \mu \mathrm{g} / \mathrm{mL}$, followed by $\mathrm{MCF}-7$, with $\mathrm{IC}_{50}$ values ranging from 5.92 to $23.97 \mu \mathrm{g} / \mathrm{mL}$, and $\mathrm{HT}-29$, with $\mathrm{IC}_{50}$ values ranging from 11.97 to $52.52 \mu \mathrm{g} / \mathrm{mL}$. All compounds were non-cytotoxic against $\mathrm{HDFn}$ with $\mathrm{IC}_{50}$ values of $>100 \mu \mathrm{g} / \mathrm{mL}$.

\section{ACKNOWLEDGEMENT}

A research grant from the De La Salle University Science Foundation, through the University Research Coordination Office, is gratefully acknowledged.

\section{REFERENCES}

Abeer Y, Ibrahim AY, Souad E, El-Gengaihi SE, Motawe HM. Phytochemical and cytotoxicity investigations of Salvadora persica bark extracts. J Arab Soc Med Res, 2011; 6(2):127-133.

Awad AB, Chinnman M, Fink CS, Bradford PG. $\beta$-Sitosterol activates Fas signaling in human breast cancer cells. Phytomed, 2007; 14:747-754.

Baskar AA, Ignacimuthu S, Paulraj G, Numair K. Chemopreventive potential of $\beta$-sitosterol in experimental colon cancer model - an in vitro and in vivo study. BMC Comp Alt Med 2010; 10:24.

Chen JR, Lin Q, Friis I, Wilmot-Dear CM, Monro AK. Urticaceae. 2003.. In: Wu ZY, Raven PH, Hong DY, editors. Flora of China. Vol. 5. Beijing, China: Science Press. pp. 78-84.

Choi YH, Kong KR, Kim YA, Jung KO, Kil JH, Rhee SH, Park $\mathrm{KY}$. Induction of Bax and activation of caspases during beta-sitosterol- mediated apoptosis in human colon cancer cells. Int J Oncol, 2003; 23(6):1657-1662.

Chudzik M, Korzonek-Szlacheta I, Król W. Triterpenes as Potentially Cytotoxic Compounds. Molec, 2015; 20:1610-1625.

Clarke PA, Hostein I, Banerji U, Di Stefano F, Maloney A, Walton M, Judson I, Workman P. Gene expression profiling of human colon cancer cells following inhibition of signal transduction by 17allylamino-17-demethoxygeldanamycin, an inhibitor of the hsp90 molecular chaperone. Oncog 2000; 19:4125-4133.

Desai KN, Wei H, Lamartiniere CA. The preventive and therapeutic potential of the squalene-containing compound. Cancer Lett 1996; 101:93-96.

Ee GCL, Lim CK, Rahmat A, Lee HL. Cytoxic activities of chemical constituents from Mesuadaphnifolia. Trop Biomed 2005; 22:99102.

Enerio JP. 2007. Bioassay-guided partial isolation of the antimicrobial components from the leaves of Pipturus arborescens. MS Thesis, MSU-Iligan Institute of Technology, Iligan City, Philippines.

Esperanza LM, KitcheGO, 2005. Inventory of Medicinal Tree Species in the Secondary Growth Forest of SitioTagkiling, Anticala, Butuan City as Utilized by the Locals.2005 NORMICIST Research and Development In-house Review. Northern Mindanao State of Science and Technology, Butuan City, Philippines.

Freshney RI. 2000. Culture of Animal Cells: A Manual of Basic Techniques. Wiley-Liss, Inc., New York, USA.

Gabona MG, 2000. Triterpenoids and other metabolites from the hexane extract of Pipturus arborescens. MS Thesis, De La Salle University, Manila, Philippines.

Geran RI, Greenberg NH, McDonald MM, Schumacher AM, Abbott BJ. Protocols for screening chemical agents and natural products against animal tumour and other biological systems. Cancer Chemother Rep 1972; 3:17-19.

Ghosh T, Maity TK, Singh J. Evaluation of antitumor activity of stigmasterol, a constituent isolated from Bacopa monnieri (Linn) aerial parts against Ehrlich ascites carcinoma in mice.Orient Pharm Exp Med 2011; 11:41-49.

Gómez MA, García MD, Sáenz MT. Cytostatic activity of Achillea ageratum L. Phytother Res 2001; 15(7):633-634.

Jacinto SD, Chun EAC, Montuno AS, Shen C-C, Espineli DL, 
Ragasa CY. Cytotoxic Cardenolide and Sterols from Calotropis gigantean. Nat Prod Commun, 2011; 6(6):803-806.

Jayaprakasha GK, Mandadi KK, Poulose SM, Jadegoud Y, Gowda GA, Patil BS. Inhibition of colon cancer growth and antioxidant activity of bioactive compounds from Poncirus trifoliate (L.) Raf. Bioorg Med Chem2007; 15:4923-4932.

Jesch ED, Seo JM, Carr TP, Lee JY. Sitosterol reduces messenger RNA and protein expression levels of Niemann-Pick C1-like 1 in FHs 74 Int cells. Nutr Res2009; 29(12):859-66.

Kaewthawee N, Brimson S. The effects of ursolic acid on cytokine production via the MPKA pathways in leukemic T-cells. EXCLI J2013; 12:102-114.

Kartika H, Li QX, Wall MM, Nakamoto ST, Iwaoka WT. Major phenolic acids and total antioxidant activity in Mamaki leaves, Pipturus albidus. J Food Sci 2007; 72(9):696-701.

Kasahara Y, Kumaki K, Katagiri S, Yasukawa K, Yamanouchi S, Takido M. Carthami flos extract and its component, stigmasterol, inhibit tumour promotion in mouse skin two-stage carcinogenesis. Phytother Res, 1994; 8(6):327-331.

Kassi E, Papoutsi Z, Pratsinis H, Aligiannis N, Manoussakis, Moutsatsou P. Ursolic acid, a naturally occurring triterpenoid, demonstrates anticancer activity on human prostate cancer cells. J Cancer Res Clin Oncol 2007; 133:493-500.

Kim H-I, Quan F-S, Kim J-E, Lee N-R, Kim HJ, Jo SJ. Inhibition of estrogen signaling through depletion of estrogen receptor alpha by ursolic acid and betulinic acid from Prunella vulgaris var. lilacina.Biochem Biophys Res Commun, 2014a; 451(2):282-287.

Kim Y-S, Li X-F, Kang K-H, Ryu B, Kim SK. Stigmasterol isolated from marine microalgae Navicula incerta induces apoptosis in human hepatoma HepG2 cells. Biochem Molec Biol Rep 2014b; 47(8):433-438.

Kumar D, Kale C, Mukundan U. Cytotoxicity against tumor cell lines of a purified mirabilis antiviral protein isolated from root of Mirabilis jalapa. World J Pharm Res 2015; 4(2):1696-1710.

Lee MN, Lee SY, Lee HJ, Seok JH, Lee CJ. Anti-proliferative effects of daidzein, baicalein, hesperidin and ursolic acid on human breast cancer cells stimulated by estrogenic compounds. Yakhak Hoechi 2010; 54(3):168-173.

Leng S, Hao Y, Du D, Xie S, Hong L, Gu H, Zhu X, Zhang J, Fan D, Kung H-F. Ursolic acid promotes cancer cell death by inducing Atg5-dependent autophagy. Int J Cancer, 2013; 133(12): 2781-2790.

Li J, Guo W-J, Yang Q-Y. Effects of ursolic acid and oleanolic acid on human colon carcinoma cell line HCT15. World J Gastroenterol., 2002; 8(3):493-495.

Liu J, Wu N, Ma L, Liu M, Liu G, Zhang Y. Oleanolic acid suppresses aerobic glycolysis in cancer cells by switching pyruvate kinase Type M isoforms. PLoS ONE 2014; 9(3): e91606. doi:10.1371/journal.pone.0091606.

Locher CP, Burch MT, Mower HF, Berestecky J, Davis H, Van Poel B, Lasure A, VandenBerghe DA, Vlietinck AJ. Anti-microbial activity and anti-complement activity of extracts obtained from selected Hawaiian medicinal plants. J Ethnopharmacol 1995; 49(1): 23-32.

Locher CP, Witvrouw M, De Bethune MP, Burch MT, Mower HF, Davis H, Lasure A, Pauwels R, De Clercq E, Vlietinck AJ. Antiviral activity of Hawaiian medicinal plants against human immunodeficiency Virus Type-1 (HIV-1). Phytomed 1996; 2(3):259-264.

Loganathan R, Radhakrisnan AK, Selvaduray KR, Nesaretnam K. Selective anti-cancer effects of palm phytonutrients on human breast cancer cells. Royal Soc Chem Adv., 2015; 5:1745-1753.

Loganathan R, Selvaduray KR, Nesaretnam K, Radhakrisnan A. Differential and antagonistic effects of palm tocotrienols and other phytonutrients (carotenoids, squalene and coenzyme Q10) on breast cancer cells in vitro. J Oil Palm Res 2013; 25:208-215.

Lu B, Liu L, Zhen X, Wu X, Zhang Y. Anti-tumor activity of triterpenoid-rich extract from bamboo shavings (Caulis bambusae in Taeniam). African J Biotechnol 2010;9:6430-6436.

Makizumi R, Yang W-L, Owen RP, Sharma RR, Ravikumar TS. Alteration of Drug Sensitivity in Human Colon Cancer Cells after
Exposure to Heat: Implications for Liver Metastasis Therapy using RFA and Chemotherapy. Int J Clin Exp Med 2008; 1:117-129.

Malek SNA, Phang CW, Ibrahim H, Wahab NA, Sim KS. Phytochemical and Cytotoxic Investigations of Alpinia mutica Rhizomes. Molec., 2011; 16:583-589.

Mitani H, Soda M, Ohshima K. Melamine production inhibitor and its use/Melanin production inhibitor usable both for external application and oral administration and its uses. Jpn. Kokai Tokkyo Koho 2000b; JP 2000290164A20001017.

Mitani H, Soda M, Ohshima K. Skin aging-preventing compositions. Jpn. Kokai Tokkyo Koho 2000a; JP 2000290165 A20001017.

Mohammed MMD, El-Sharkawy ER, Matloub AA. Cytotoxic flavonoids from Diplotaxis harra (Forssk.) Boiss. growing in Sinai. J Med Plants Res 2011; 5(20):5099-5103.

Moon DO, Kyeong JL, Yung HC, Gi-Young K. $\beta$-Sitosterolinduced-apoptosis is mediated by the activation of ERK and the downregulation of Akt in MCA-102 murine fibrosarcoma cells. Int Immunopharmacol, 2007; 7:1044-1053.

Neto CC, 2011. Ursolic acid and other pentacyclic triterpenoids anticancer activities and occurrence in berries. In: Stoner GD and Seeram NP (Eds.). Berries and Cancer Prevention. Springer Science+Business Media, LLC 41-49.

Oguro T, Liu J, Klaassen CD, Yoshida T. Inhibitory Effect of Oleanolic Acid on 12-O-Tetradecanoylphorbol-13-acetate-lnduced Gene Expression in Mouse Skin. Toxicol Sci 1998; 45:88-93.

Panda S, Jafri M, Kar A, Meheta BK. Thyroid inhibitory, antiperoxidative and hypoglycemic effects of stigmasterol, isolated from Butea monosperma. Fitoter 2009; 80(2): 123-126.

Pelser PB, Barcelona JF, Nickrent DL (Eds.), 2011.Co's Digital Flora of the Philippines. Available at http://www.philippineplants.org/ CoFamsPDF/URTICACEAE [Accessed 12 Jul 2015].

Peteros NP, Uy MM. Antioxidant and cytotoxic activities and phytochemical screening of four Philippine medicinal plants. J Med Plants Res 2010;4(5):407-414.

Peteros NP, 2010. Studies on the structures and bioactivities of components of selected Philippine medicinal plants. PhD Dissertation, MSU-Iligan Institute of Technology, Iligan City, Philippines.

Prabhu A, Krishnamoorthy M, Prasad DJ, Naik P. Anticancer activity of friedelin isolated from ethanolic leaf extract of Cassia tora on HeLa and HSC-1 cell lines. Indian J Appl Res 2013; 3(10):1-4.

Quisumbing E, 1978. Medicinal Plants of the Philippines. Quezon City, Philippines: Katha Publishing Co., Inc., JMC Press, Inc.

Ragasa CY, Ng VAS, Ebajo Jr. VD, De Los Reyes MM, Mandia EH, Shen C-C. Chemical constituents of Pipturus arborescens (Link) C.B. Rob.. Der Pharmacia Lettre 2014; 6(6):35-42.

Rao CV, Mark HLN, Reddy RS. Chemopreventive effect of squalene on colon cancer. Carcinogenesis, 1998; 19:287-290.

Ronco AL, De Stéfani E. Squalene: a multi-task link in the crossroads of cancer and aging. Functional Foods in Health and Disease 2013; 3:462-476.

Rosal RR, 1995. Bioassay-guided isolation and structure elucidation of some metabolites from Pipturus arborescens .MS Thesis, De La Salle University, Manila, Philippines.

Sangsuwon C, Jiratchariyakul W, U-pratya Y, Kummalue T. Antiproliferative Effect and the Isolated Compounds of Pouzolzia indica. Evid-Based Compl Alt Med 2013; 2013:1-8.

Scholtysek C, Krukiewicz AA, Alonso J-L, Sharma KP, Sharma PC, Goldmann WH. Characterizing components of the Saw Palmetto Berry Extract (SPBE) on prostate cancer cell growth and traction. BiochemBiophys Res Commun 2009; 379:795-798.

Shen S, Zhang Y, Zhang R, Tu X, Gong X. Ursolic acid induces autophagy in U87MG cells via ROS-dependent endoplasmic reticulum stress. Chemico-Biol Interact 2014; 218:28-41.

Sung B, Chung HS, Kim M, Kang YJ, Kim DH, Hwang SY, Kim MJ, Kim CM, Chung HY, Kim ND. Cytotoxic effects of solventextracted active components of Salvia miltiorrhiza Bunge on human cancer cell lines. ExpTher Med 2015; 9:1421-1428. 
Utami R, Khalid N, Sukari MA, Rahmani M, Dachriyanus ABA. Phenolic contents, antioxidant and cytotoxic activities of Elaeocarpus floribundus Blume.Pak J Pharm Sci 2013; 26(2):245-250.

Uy MM, Rivera AP. Studies on the structure and biological activity of the chemical constituents of the leaves of ipil, handalamay and lipang-aso. NRCP Res J 2011; 11(1):1-9.

VanValkenburg JLCH, 2001. Pipturus arborescens (Link) C.B. Robinson. In: van JLCH Valkenburg; N Bunyapraphatsara (Eds.). Plant Resources of South-East Asia No. 12(2): Medicinal and Poisonous Plants 2. Leiden, The Netherlands: Backhuys Publisher 432.

Wang W, Zhao C, Jou D, Lu J, Zhang C, Lin L, Lin J. Ursolic acid inhibits the growth of colon cancer-initiating cells by targeting STAT3. Anticancer Res, 2013; 33(10):4279-4284.

Wang X, Zhang F, Yang L, Mei Y, Long H, Zhang X, Zhang J, Su Q-S. Ursolic acid inhibits proliferation and induces apoptosis of cancer cells in vitro and in vivo. J Biomed Biotechnol 2011; Article ID 419343, 8 pages.

Zhang M, Shen Y. The anti-cancer effects of ursolic acid and oleanolic acid in the digestive system, A Review. Shanghai Yiyao, 2011; 32(12):606-611.

\section{How to cite this article:}

Mariquit M. De Los Reyes, Glenn G. Oyong, Virgilio D. Ebajo Jr., Vincent Antonio S. Ng, Chien-Chang Shen, Consolacion Y. Ragasa. Cytotoxic Triterpenes and Sterols from Pipturus arborescens (Link) C.B. Rob. J App Pharm Sci, 2015; 5 (11): 023-

030 . 